Jane Gary Harris

\title{
RE-IMAGINING RUSSIA'S SOCIAL CARE SYSTEM \\ IN THE AGE OF THE INTERNET: THE GERONTOLOGICAL NGO DOBROE DELO, THE MADRID PLAN, AND THE RIGHTS OF THE ELDERLY
}

Over the past 25 years, Russia's social care system for older adults has experienced significant challenges and changes. This paper explores the rationale behind those challenges and the agency behind the changes. In doing so it raises several questions: it asks what role NGOs, and more specifically, Gerontological NGOs, played in advocating for and bringing about change, where and how they may or should be credited with helping to re-imagine a modern aging policy for the Russian Federation, and what implications this may have for aging policy priorities in the present and imminent future? It proposes that the incipient Gerontological NGO sector was instrumental in re-imagining a modern social care system for older persons - the basis for a modern comprehensive aging policy: by, among other things, utilizing the internet in the social sphere to advocate for the principles and recommendations of the United Nations model Madrid Plan; by advocating for the rights of the elderly; by calling for integrated social and medical care; and by linking gerontological research and aging policy. An inquiry into the nature of the influence of these NGOs on aging policy priorities required a micro-level examination of the particularly influential Gerontological NGO Dobroe Delo, suggesting its seminal role in unifying an inchoate Gerontological NGO sector, while simultaneously transforming the basic paradigm of aging policy to focus on the 'Rights of the Elderly.' In addition, this paper proposes that such research is critical to understanding how Russia's aging policy has been re-imagined over the past decade and a half while asking what policy issues yet remain to confront future demographic demands.

Key words: aging policy, gerontological NGO, internet, Madrid Plan, rights of the elderly, Dobroe Delo

DOI: $10.17323 / 727-0634-2018-16-1-155-168$

Jane Gary Harris - Professor emerita, Department of Slavic Languages, Literatures and Cultures, and MSW in Gerontology, University of Pittsburgh, USA. Email: jgharris@pitt.edu 


\section{Introduction}

Over the past 25 years, Russia's social care system for older adults has experienced significant challenges and changes. In the Soviet Union, social provision for the elderly was extremely limited; life expectancy was too low to prioritize aging policy. Senior care was perceived as a family burden and responsibility, not a welfare issue. Stereotypical images of the old and negative attitudes towards aging dominated, effectively limiting 'safety net' provision. More recently, major aging policy changes have been implemented.

This paper explores the rationale behind the challenges and the agency behind the changes, thus, questioning the role played by NGOs, and asking where and how they may be credited with helping to re-imagine a modern aging policy for the Russian Federation. Furthermore, the implications this has for future aging policy priorities are considered. This paper proposes that NGOs - specifically the incipient gerontological NGO sector - were instrumental in re-imagining a modern social care system - the basis for a modern aging policy engendered by (1) introducing and utilizing the internet in the social sphere; (2) advocating for the Madrid Plan; (3) linking gerontological research and aging policy; (4) advocating for the rights of the elderly; and (5) calling for integrated social and medical care. An inquiry into the nature of the influence of Gerontolgical NGOs on aging policy priorities required a micro-level examination (Thomson 2011) of the particularly influential NGO Dobroe Delo, suggesting its seminal role in unifying an inchoate Gerontological NGO sector, and in the process, transforming the basic paradigm of aging policy from 'safety net' provision to a human rights agenda, focused on the rights of the elderly. It is proposed that this research is critical to understanding the process of how Russia's aging policy has been re-imagined over the past decade and a half while asking what policy issues currently remain to confront future demographic demands.

This paper opens with the socio-historical context, namely the Soviet policy of Sobes ('social protection'). Second, it reviews the post-socialist policy of the 1990s and the rise of community-based care and social work (Centers for Social Services). Third, it centers on a micro-level examination of how the NGO Dobroe Delo and the Gerontological NGO sector advocated both for the transformation of attitudes towards aging and older adults and the concomitant modernization of the post-socialist social care system. It is proposed that the use of the internet (Wong at al. 2011) and promotion of the United Nations model Madrid Plan for Action on Ageing (MPIAA) (United Nations 2002; Zelenev 2008: 1-17) were fundamental instruments of change in aging policy.

\section{The Socio-historical context}

Sobes, the Soviet policy of 'social protection', reflects a paternalistic system based on traditional stereotypes of 'older persons' or 'pensioners' as 'a bur- 
den' on society. Assumed to be no longer capable of contributing to society, 'pensioners' were all represented as a separate category, never as individual citizens (Grigoryeva 2007). Thus, aging policy originated as a means to provide a minimum 'safety net' for older persons lacking family care: eligibility for minimal institutional care. If senior care was a family responsibility, Sobes functioned to alleviate that burden, but rarely considered the individual perspective, the manner of care, or the environment. This dilemma is brilliantly portrayed by Liudmila Petrushevskaia in her novella Vremia Noch [The Time is Night] (Petrushevskaia 2001: 125-175).

In the early Post-Socialist years, even such minimal care facilities were in a parlous state due to the national crisis. The early 1990 s perceived social care as an 'emergency' response not only to the financial crisis (including the massive unemployment of women and impoverishment of 'pensioners'), but also to the pending demographic crisis, and the ongoing healthcare crisis, traced back to the 1970s (Tragakes 2003). While the traditional stereotype of 'pensioners' persisted, gerontologists and socially conscious political leaders began to take note of alternative models of senior care provision based on Eriksonian psychosocial theories of lifespan development and the rethinking of 'life's developmental tasks' (Erikson 1997). By the 1990s, those familiar with the 1991 UN document, Principles for Older Persons, emphasized that in addition to guaranteed end of life medical and social care (the under-fulfilled promise of 'social protection'), the rights of older adults to independence, self-fulfillment, dignity, and full participation in society must be recognized. Hence, the impetus behind the first post-socialist Federal laws, effective in 1995 'On Social Services for the Elderly and Disabled' and 'On the Basis of Social Services in the Russian Federation' (Federal Law 1995 a, 1995b). Only twenty years later were those laws replaced by a new Federal Law N 442-FZ (2013), discussed in parliament in 2013, operative as of January 2015, calling for the modernization of attitudes towards older adults and updated social care.

Briefly, the 1995 laws led to the creation of emergency-focused, CommunityBased Centers of Social Services in contradistinction to Sobes' reliance on institutional care. The Centers began to function in the early 1990s throughout the Russian Federation. Intended to have broad reach in providing community-based care and emergency services to the impoverished, while coordinating home care for homebound elderly without families, for the disabled, and other needy persons, the Centers were both more cost effective and more humane than the older facilities, and over time, far more innovative (Golianich et al. 2007; Harris 2011).

The central problem arising from the 1995 Laws was how to staff the Centers. Due to the crisis, the need for increased social provision emerged as an emergency response before adequate personnel could be trained; thus, thousands of positions as home care aides were filled by thousands of untrained, unemployed women made available by the crisis (a significant gender issue). Even today, almost $80 \%$ of Center services continue to focus on home 
care and emergency services (Iarskaia-Smirnova 2002, 2004; Romm et al. 1999; Golianich et al. 2007). However, the need to train social work cadres was clearly recognized: several Service Academies were founded while Faculties of Social Work were newly organized at established universities and institutes. Nevertheless, the introduction of modern social work theory and practice into the social welfare system continues to be a work in progress (Anisimov, Ar'ev 2005-2008; Panich 2004-2009; Grigoryeva 2011).

By the early 2000s, with the welcome stabilization of the economy and availability of newly trained social work personnel, the immediate question was how to develop and expand services beyond emergency provision? Fortunately, this coincided both with the UN publication of The Madrid Plan for Action on Ageing (United Nations 2002), considered the 'gold standard' by gerontologists, and the concomitant rise of Gerontological NGOs in the Russian Federation. This appeared to provide an opportunity to re-imagine the entire Russian social care system and challenge traditional stereotypes along two basic lines. First, the demographic revolution could be related to modern concepts of social gerontology and geriatric care promulgated in the internationally celebrated Madrid Plan. Second, new attention could be paid to Eriksonian 'life span development' and the psychosocial dimension of aging (not merely subsistence care). This major challenge included reconfiguring the principles of aging policy to include the human rights agenda, a new outlook demanding a new terminology, and a focus on such modern social gerontological concepts as 'Quality of Life,' 'Third Age,' 'Rights of the Elderly,' 'Society for All Ages,' 'Healthy and Active Aging'.

\section{The Madrid Plan (MPIAA)}

Why was the Madrid Plan considered the 'gold standard' for gerontologists and geriatric care? How did the Russian government respond? The MPIAA expands both the UN's 1982 Vienna Plan, which focused on economic and social support ('social protection'), and its 1991 Principles for Older Persons, calling for the Rights of the Elderly to 'independence, self-fulfillment, dignity, and full participation in society' as well as a guaranteed continuum of medical and social care. The MPIAA declared the 'transformation of attitudes towards senior citizens' must be the 'foundation for all programs and services.' Its primary recommendations include: (1) Celebration of longevity and 'active aging' as 'one of humanity's major achievements,' thus the challenge 'to promote increased opportunities for older persons...to enjoy a life of fulfillment, health, security, and active participation in the economic, social, cultural and political life of their societies' (Article 2); (2) The input of multiple stakeholders, e.g., family, civil society, and older persons themselves, while recognizing the 'primary responsibility of governments to ensure access to basic social services, mindful of specific needs of older persons' (Articles 13, 15, 16, 17); (3) The 
elimination of 'Ageism' (Article 5); (4) monitoring, and research 'on ageing as an instrument for the formulation of policies on ageing' (Article 11); (5) employment opportunities as essential to 'active ageing' (Article 12); (6) healthcare as 'a continuum of care from disease prevention to...palliative care...' (Article 14); (7) training, education, and access to information for professionals and para-professionals (United Nations 2002).

The Russian government response was more than pro forma acceptance. Its report to the UN Secretary General contextualized the MPIAA within existing state policy: i.e. pensions and labor policy (Cook 2011). While the State's Federal Specially Designated Plan (Tselevaia Programa) 'The Older Generation for 2002-2004' focused on pensions and healthcare, locally, regions and municipalities sponsored their own Plans, e.g. (The Government Decree 2002), the city of St Petersburg as well as the Kursk Regional Administration proposed to help realize the cultural, psychological, and intellectual needs of older people, designated as 'social rehabilitation' (Harris 2007). Medvedev's Strategy for Action for Older People for 2025 continues this focus, but adds MPIAA language to 'create a society for all ages' (The Russian Government 2015).

\section{The Gerontological NGO Dobroe Delo}

How did the parallel rise of Gerontological NGOs and the theory and practice of social gerontology in Russia challenge traditional attitudes and stereotypes, and thus help to modernize aging policy? How did the MPIAA challenge the institutions of emergency care and help transform them into modern institutions of preventive support services and social rehabilitation, engendering the principles of Federal Law 442?

To understand the evolution of these challenges and changes in aging policy, this paper focuses on a micro-level examination of a key NGO, delineating its emergence in the context of Russian aging policy leading up to the adoption of Federal Law 442, which finally accords official recognition to the role of Gerontological NGOs in social care provision, authorizing their participation in Russia's senior care system. Dobroe Delo was selected due to its seminal influence both on the development of the Gerontological NGO sector and on concomitant efforts to modernize the paradigm for aging policy. While most NGOs and social organizations concerned with older adults focused on single issues, i.e. healthcare, legal problems, educational or leisure time programs, Dobroe Delo actively employed the internet to re-imagine aging policy as an integrated whole dedicated to promoting the rights of the elderly (Thomson 2011; Tarasenko 2015).

Dobroe Delo, a small socially oriented Gerontological NGO, founded in Moscow by two physicians and a nurse practitioner in 2000, was inspired to advocate for, and implement the principles, priorities and practices of the Madrid Plan in Russia. It was strongly influenced by publications of the International Federation of Ageing, after joining it in 2001. Besides establishing 
a model community-based geriatric home health care agency, emphasizing the novel idea of integrating social and medical care to serve its 200 (now 800) homebound patients, its mission greatly expanded by 2002 through its emphasis on employing the internet in the social sphere. Through its website, electronic and print publications, it helped establish and consolidate a functioning Gerontological NGO network to promote research, advocacy, and the organizing of seminars and trainings throughout Russia to promote and implement the MPIAA and 'Rights of the Elderly.' The Director, Eduard V. Kariukhin, a specialist in gerontology and geriatric medicine, had been employed by the Memorial Foundation since 1989, serving patients returning from Stalinist camps. In planning their new geriatric center in Moscow, he and his colleagues soon realized that the issues facing camp survivors resulted not only from living under extreme conditions, but were problems faced daily by aging senior citizens throughout Russia. Hence, Dobroe Delo resolved that its mission must include providing immediate access to information and advocating for the rights of all older persons according to the principles and recommendations of the MPIAA, first within Russia, and later, the CIS.

\section{Dobroe Delo, the Gerontological NGO sector and the Internet}

Dobroe Delo, as a small, determined and active Gerontological NGO, could be quite flexible and innovative in its policies and programs. Accepting the Madrid Plan's mandate, it began to adopt its principles and philosophical orientation systematically. During the key years of the early 2000s, Dobroe Delo received funding from American and British organizations and the European Commission as well as local Russian charities, allowing it to expand its activities and provide essential information through its website introducing and advocating international standards. Its mission was three-fold: improving the quality of life for seniors; encouraging regional Gerontological NGOs; and organizing scientific research in social gerontology.

Between 2002 and 2006, it organized regional seminars for NGOs supporting older adults from Petrozavodsk to Omsk as well as in St Petersburg and Moscow, inviting leaders of NGOs of all types, including pensioners' and veterans' organizations along with local government administrators and Center directors. It involved as many organizations as possible in partnerships, promoting the concept that NGOs could act as a 'hopeful partner to the state system of social protection for seniors' (Dobroe Delo 2018). Results included: the inauguration of the Dobroe Delo website, which then published all Russian language UN documents on Older Persons and printed Gerontological NGOs: From Models of Care to the Establishment of the Sector (Kariukhin 2002); most significant, after surveying existing NGOs and NGO Resource centers as new NGOs were founded throughout the RF, was the consolidation of the 'Social sector for the support of seniors' and formation of The Interregional Coalition of Gerontological NGOs 
(Kariukhin 2006c), along with the introduction of courses and certification for regional personnel provided through distance learning.

In 2003, the Coalition summarized its experiences working with human rights issues and legal activities for the Commission on Human Rights in the President's Council of the RF, as proposals by Gerontological NGOs were incorporated into preparations for the first all-Russian meeting of social organizations intended for March 2004. These included: the creation of a National Center on Aging Policy; an independent Inspection System to monitor social services; making Elder Law an independent legal discipline; a Law on government standards for social services; introducing the Declaration of Rights of Older People into all old age facilities; publishing an internet journal on The Rights of the Elderly (Prava pozhilykh) - realized on Dobroe Delo's Facebook page; support for the participation of social organizations in geriatric care (i.e. integrating social and medical care professionals); and establishing a dedicated Geriatric Center in Moscow for both outpatient medical care and scientific research (Kariukhin 2006c).

In addition to the electronic publications of 2002-2004, the next three years witnessed a host of key print publications (initially, very few organizations had internet connections) - on legal rights as well as medical and social provision - and in 2006 a set of Compact Discs on the protection of the rights of the elderly. Distributed free of charge to all interested social organizations, educational institutions, e.g. Znanie society branches in Russia's regions, as well as government organizations, they advocated for the MPIAA human rights platform to supersede the limited, paternalistic Soviet concept of 'social protection' as well as efforts to partner with state structures to improve social support for all senior citizens (Kariukhin 2002, 2004, 2006).

2007 was even more critical to the growth and influence of Dobroe Delo and the GNGO sector as it brought the MPIAA and the psychosocial concept of 'Healthy and Active Ageing' to the forefront of Russian social consciousness. That summer the IAGG (International Association of Gerontology and Geriatrics) held its annual Congress in St. Petersburg in conjunction with the VI European Congress. Its theme loudly proclaimed the ideals of the Madrid Plan: 'Healthy and Active Aging for all Europeans in the Framework of the United Nations Research Agenda on Ageing for the $21^{\text {st }}$ Century' (IAGG 2007). In honor of this event, Alexandre Sidorenko, Coordinator of the UN Program on Aging, spoke on 'Education as an Important Dimension of National Capacity Building for Implementing the MPIAA,' while Eduard Kariukhin presented his paper 'Aging policy in Russia'. Dobroe Delo published a booklet introducing its programs and accomplishments (Kariukhin 2007). Unfortunately, while e-mail invitations were sent to all organizations associated with aging issues and senior care, only those with internet access (or who read their e-mails) sent representatives. ${ }^{1}$

\footnotetext{
${ }^{1}$ For example the Gerontological NGO sector received invitations but most of the state operated Centers for Social Services did not (Personal interviews).
} 
By 2010, Vestnik Koalitsii, the Journal of the Coalition, expanded its electronic publishing to involve Eurasia, producing the Information Bulletin, Starenie v Evrazii, a project supported by HelpAge International, Bishkek, Kyrgyzstan (Kariukhin et al. 2010). The website also initiated Verenitsy: an online international literary-arts almanac for older people to which Russian, CIS, and international seniors were invited to submit original work such as drawings, poems, stories, and memoirs (Ibid).

\section{Implementation of the Madrid Plan}

With regard to implementing aspects of the Madrid Plan, 2010 seems to have been a turning point for the government as well. President Medvedev spoke at a State Council Presidium meeting on October 25 about social policy for senior citizens and recommendations for raising their 'quality of life' (President of Russia 2010). While the Federal Government focused primarily on material security, local and regional governments were assigned to improve social care services through the Centers for Social Services.

On the other hand, there was no mention of the MPIAA's human rights agenda, nor efforts to alter attitudes towards the elderly; no mention of the rights of senior citizens to participate in activities of daily life to realize the concept of 'active and healthy ageing.' Hence, no mention of the psychosocial dimension of human development, e.g. education, socialization, cultural or leisure time activities, nor any focus on social rehabilitation. Nevertheless, individual Center Directors and support organizations could exert their independence in creating meaningful and novel programs to respond to the psychosocial demands of 'active aging.' Some Center directors were inspired by the Madrid Plan to set up Schools of the Third Age in St. Petersburg, Arkhangelsk, Vologda, Orel, among others (Danilova 2006; Chernysheva 2006) introducing classes on computer literacy, Russian culture, health management, physical education, nutrition; to organize local excursions, plan intergenerational activities, encourage volunteerism among seniors (Danilova 2005). Special interest clubs were also developed at many Centers (Harris 2011; Panich 2004-2009).

Over the years, Dobroe Delo sought through its website and the Coalition to support the growth of gerontological organizations throughout Russia and the CIS. It has maintained links with socially oriented and gerontological NGOs, nationally and internationally, developed partnerships with local and regional government organizations and state-run Centers for Social Services, and promoted international models of 'best care practices'. The Coalition has continued to provide informational and educational support through its Virtual Resource Center for Gerontological NGOs on the website ${ }^{1}$, and its designated page for

\footnotetext{
${ }^{1}$ See http://dobroedelo.org/koaliciya-pravo-pozhilyx/
} 
legal information, Gerontological Legal Defense. ${ }^{1}$ It continued to add resources, i.e. Facebook pages under the headings 'Pravo pozhilykh' ('Rights of the Elderly') and 'Aktivnoe starenie' (Active Ageing) as well as a Twitter account. In December 2014, it initiated a new electronic bulletin, Informatsionnyi Biulleten' 'Pravo Pozhilykh,' (Information Bulletin: Rights of the Elderly) containing articles, interviews, and basic information (Dobroe Delo 2018).

In addition to gerontological research, advocacy for gerontological legal aid and defense has been a priority from the earliest days. This continues through educational programs illuminating the Rights of the Elderly; sending complaints and appeals to the authorities to defend the interests and rights of individuals and groups of elderly people; summarizing the practical and theoretical materials dealing with the protection of legal rights of older people; establishing partnerships with lawyers and legal scholars. Research in areas of social gerontology has included the creation and analysis of models of geriatric care by GNGOS and studies of the social functioning of older adults, most recently in rural Russia. Working closely with HelpAge International, an analysis of their joint seminar and research project was electronically published in 2016: 'How to Strengthen Rural Associations of Older People,' based on research in Kamensk-Ural'skii in the Sverdlovsk region and Rubtsovsk in the Altai (Dobroe Delo 2014-2016).

\section{Foreign Agent Law of 2012: setbacks and response}

Despite serious setbacks caused by the Foreign Agent Law of 2012, especially the loss of funding from foreign sources, the Dobroe Delo website and the Coalition continued to issue critiques of aging policy not only in Russia but in the CIS, to promote conferences, seminars, trainings, and roundtables on aging policy, and to petition for major changes at the Ministry of Health and Social Services. In 2012, it called on Minister Tatiana Golikova to make monitoring of nursing homes (internaty) a reality; requested that members of civil society organizations be appointed to the Monitoring Commission of the Russian Health Inspectorate (Roszdravnadzor); and called for an Ombudsman. While the response received by Dobroe Delo was minimal: a Ministry request was made to document cases of abuse, but Commission membership was not granted. Nonetheless, Dobroe Delo viewed this as a 'first step'.

Throughout the spring of 2013, the website posted articles from an array of news sources criticizing the 'foreign agent law,' however, on June 13, Dobroe Delo posted its own forthright views on its Facebook page 'Aktivnoe starenie,' expressing how the controversy was harming NGOs not considered politically hostile:

\footnotetext{
${ }^{1}$ See http://dobroedelo.org/tag/elektronnyj-byulleten-pravo-pozhilyx/
} 
Developing any non-governmental activity is becoming dangerous. An atmosphere of fear is being imposed on society $<\ldots>$ Russian intellectuals are being transformed into foreigners, and Russian NGOs are being re-registered. The work of experts is being questioned as representatives of the intellectual elite are forced to answer the question: 'Is it worth it to stay in Russia?' Reasonable and modest citizens, not radicals, are being forced out of social life.

The website continued to publish articles on the pros and cons of the law in subsequent years, even as the rules tightened (Tarasenko 2015).

\section{Gerontological NGO influence on state organizations: Federal Law 442, and The Strategy for 2025}

Meanwhile, the website continually promoted new web resources for older adults, and posted announcements of new cultural and educational programs, for example, in 2016, it was able to announce the distribution of donated computers to Gerontological NGO centers. Ironically, in this era of suspicion of foreign funded projects, two major research studies were carried to fruition with international backing: the above-mentioned study of rural aging, and a joint Russian-American exchange involving reciprocal visits of gerontologists to review each other's programs for older adults. ${ }^{1}$ While major changes have greatly improved programs for seniors in the cities through innovative planning in the Centers (Harris 2011), it has taken far longer for the concepts of the MPIAA and Internet access to reach the provinces. However, it is clear that Dobroe Delo, the Coalition, and the website have significantly influenced the thinking of local and regional administrators regarding the entire spectrum of social and medical care provision and, indeed, on advocating for the rights of older persons in accord with the MPIAA to practice 'active and healthy ageing,' with assurances of adequate social and medical support.

This was exhibited clearly in the Dobroe Delo website's publication of President Putin's August 2014 speech (preceding implementation of Federal Law 442-FZ) to a working group session of the State Council Presidium meeting in Voronezh, which included the response of local governors. It suggests that efforts to provide access to information to the regional authorities about modern aging policy and gerontological research were not in vain. In contrast to Putin's benign acceptance of what he viewed as major signs of pensioners' improved 'quality of life' (higher pensions, improved longevity), regional governors emerged as less sanguine: they requested 'equal funding' to all the regions and called for 'modern' geriatric services and training of social and medical personnel in geriatric care. For example, Vladimir Yakushev, Governor of Tiumen region, claimed it was 'time to apply international expertise,' that 'new models' for

\footnotetext{
${ }^{1}$ As Professor of Gerontology Dr. William E. Hills revealed to me in personal correspondence, the latter was sponsored by the US-Russia Peer-to-Peer Dialogue Grant Program 2015-16.
} 
geriatric care were required 'both in rehabilitation and palliative care services, along with medical security for bed-ridden patients'. Moreover, he called for the application of 'contemporary gerontological approaches to all aspects of older peoples' lives, including nutrition, physical activity, support therapies, psychological support, and other elements of social adaptation' (President of Russia 2014). But despite good intentions, no additional funds were made available in 2014-2016 for increased pensions; indeed, the government even cut social funding. Putin stated, 'we cannot do it all immediately' (Ibid).

Federal Law 442-FZ became operative on January 1, 2015, revising and redefining key principles of social services in the Russian Federation. It differs from previous laws in four key respects, reflecting the MPIAA. First, it focuses on 'Prevention,' and addresses the need for an 'Individual approach, such as drawing up "Individual treatment plans" for each client. Second, it promotes the concepts of "social support services" and "social rehabilitation," which Article 28 defines as providing citizens with the "necessary assistance in obtaining required medical, psychological, educational, legal, and social assistance." Third, it officially recognizes socially oriented NGOs and private business, so they may now be paid to carry out provisions of the new law in conjunction with, or in addition to, state-operated organizations. Fourth, it makes non-professional persons, i.e. family members or neighbors, eligible to receive payments for services rendered, if they can obtain accreditation (Federal Law 2015).

\section{Observations and Conclusions}

Thus, in evaluating the overall effects of the process of paradigm change in aging policy, major improvements - both in social policy priorities and social care provision - can be attributed to the advocacy of Dobroe Delo and the Inter-Regional Coalition of Gerontological NGOs initiated in the early 2000s. In employing the internet in the social sphere to advocate for the Madrid Plan, Dobroe Delo deserves credit for being a prime instigator and contributor to the realization and acceleration of significant changes in aging policy, practice, and research, and for demonstrating how alternative policy priorities can be promulgated through networking. Nevertheless, completely fulfilling the mandate of the Madrid Plan remains a distant goal.

Hopefully, a clearer understanding of this process and its achievements to date may help focus ongoing and future policy challenges. For example, implementing the proposals offered by Dobroe Delo and the Coalition back in 2003 would provide much needed coordination and integration of social and medical care policies, i.e. the creation of a National Center on Aging Policy; an independent Inspection System to monitor social services; making Elder Law an independent legal discipline; introducing the Declaration of Rights of Older People into all old age facilities, among other things. However, while the State has finally offered a long term 'Strategy of Action in the Interest of the Older Population of the Rus- 
sian Federation to 2025' (The Russian Government 2015) to meet the inevitable demands of the demographic revolution, its policy outcome is uncertain. Nevertheless, the first stage of its realization has been confirmed by the government for the next five years.

\section{References}

Anisimov A., Ar'ev A. (eds.) (2005-2008) Pushkovskie Chteniia. I, II, III IV Nauchno-prakticheskaia gerontologicheskaia konferentsiia s mezhdunarodnym uchastiem, posviashchennaia pamiati E. S. Pushkova. Tezisy dokladov [Pushkova Conference Presentations. I, II, III, IV Scholarly-Practical Gerontological Conferences with International Participation, Dedicated to the Memory of E. S. Pushkova. 2005-2008. Theses]. St Petersburg: Gorodskoi geriatricheskii tsentr.

Chernysheva S. (2006) Aktiviziruiushchie tekhnologii sotsial'noi raboty s pozhilymi liud'mi (proekt 'Shkola Tret'ego Vozrasta') [Enacting Technologies of Social Work for the Elderly (the Project 'School of the Third Age']. Pushkovskie Chteniia. II Nauchno-prakticheskaia gerontologicheskaia konferentsiia s mezhdunarodnym uchastiem, posviashchennaia pamiati E.S. Pushkova. 30 noiabria-1 dekabria 2006 g. Tezisy dokladov [E. S. Pushkova Conference Presentations. II Scholarly-Practical Gerontological Conference with International Participation, Dedicated to the Memory of E. Pushkova. Nov 30-Dec 1, 2006. Theses]. St. Petersburg: 73-75.

Cook L. (2006) NGOs and Social Policy Making in Russia's Regions. Problems of Post-Communism, 53 (5): 28-41.

Cook L. (2011) Russia's Welfare Regime: the Shift toward Statism. In M. Jappinen, M. Kulmala, A. Saarinen (eds.) Gazing at Welfare, Gender and Agency in Post-Socialist Countries. Cambridge: Cambridge Scholars Publishing: 14-35.

Danilova R. (ed.) (2005) Rukovodstvo po organizatsii volonterskoi (dobrovol'noi) deiatel'nosti sredi pozhilykh i dlia pozhilykh [Leadership in Organizations of Volunteer Activity Among the Elderly and for the Elderly]. Arkhangelsk: Pomorsk Gos. Universitet.

Danilova R. (2006) Gerontosotsial'naia rabota v Rossii v kontekste Madridskogo Mezhdunarodnogo plana deistvii po problemam stareniia naseleniia [Gerontological Social Work in Russia in the Context of the Madrid Plan for Action on Problems of the Aging Population]. Pushkovskie Chteniia. II Nauchno-prakticheskaia gerontologicheskaia konferentsiia s mezhdunarodnym uchastiem, posviashchennaia pamiati 30 noiabria-1 dekabria 2006 g. Tezisy dokladov. [E. S. Pushkova Conference Presentations. II Scholarly-Practical Gerontological Conference with International Participation, Dedicated to the Memory of E. S. Pushkova. Nov 30-Dec 1, 2006. Theses]. St. Petersburg: $40-42$.

Dobroe Delo (2014) Sel'skaia meditsina dlia pozhilykh: Seminar v selo Novoisetskoe. Available at: http://dobroedelo.org/new/selskaya-medicina-dlya-pozhilyx-seminar-v-s-novoisetskoe (accessed (accessed 5 September 2016).

Dobroe Delo (2016) Analiticheskaia zapiska: Vyvody i rekomendatsii zavershennogo mezhdunarodnogo proekta [Analytic Memorandum: Conclusions and Recommendations from the Completed International Project (2016) Dobroe Delo]. Available at: http://dobroedelo.org/new/analiticheskayazapiska-vyvody-i-rekomendacii-zavershennogo-mezhdunarodnogo-proekta/ (accessed 5 Sept 2016). DobroeDelo (2018) Website. Available at: http://dobroedelo.org/ (accessed 1 February 2018).

Erikson E. (1997) The Life Cycle Completed. Extended version with New Chapters on the Ninth Stage of Development by Joan M. Erikson. New York: W. W. Norton.

Federal Law (1995a) O social'nom obsluzhivanii grazhdan pozhilogo vozrasta i invalidov, No 122-FZ ot 02.08. 1995 [On Social Services for the Elderly and Disabled]. Available at: http:// ivo.garant.ru/\#/document/10103878/paragraph/10577:0 (accessed 13 February 2015).

Federal Law (1995b) Ob osnovakh sotsial'nogo obsluzhivaniya naseleniya v Rossiyskoy Federatsii, No 195-FZ ot 10.10.1995 [On the Basis of Social Services in the Russian Federation] Available at: http://base.garant.ru/105642/ (accessed 13 February 2015). 
Federal Law (2015) Ob osnovakh sotsial'nogo obsluzhivaniia grazhdan v Rossiiskoi Federatsii [On the Basis of Social Services in the Russian Federation] N 442-FZ from 28.12.2013.

Golianich V., Grigorieva I., Kliuev A. (2007) Strategicheskoe razvitie sotsial'noi sfery, sluzhb i organizatsii, rabotaiushchikh s pozhilymi liud'mi [Strategic Development of the Social Sphere, Services, and Organizations Working with the Elderly]. St. Petersburg.

Grigoryeva I. (2005) Prioritety sotsial'noi politiki: pozhilye liudi [Priorities of Social Policy for the Elderly]. Zhurnal sotsiologii i sotsial'noi antropologii [Journal of Sociology and Social Anthropology], 3 (8): 131-145.

Grigoryeva I. (2006) Sotsial'naia politika v otnoshenii pozhilykh v Rossii: vyzov reformam $\mathrm{i}$ traditsiam [Social Policy Regarding the Elderly in Russia: Challenges to Reforms and Traditions]. Pushkovskie Chteniia. II Nauchno-prakticheskaia gerontologicheskaia konferentsiia s mezhdunarodnym uchastiem, posviashchennaia pamiati E. S. Pushkova. 30 noiabria-1 dekabria 2006 g. Tezisy dokladov [E. S. Pushkova Conference Presentations. II Scholarly-Practical Gerontological Conference with International Participation, Dedicated to the Memory of E. S. Pushkova. Nov 30-Dec 1, 2006. Theses]. St. Petersburg:36-37.

Grigoryeva I. (2007) Starenie naseleniia i sotsial'naia rabota s pozhilymi: v chem problema? [Population Aging and Social Work with the Elderly: What are the Main Issues?]. Pushkovskie Chteniia. III Nauchno-prakticheskaia gerontologicheskaia konferentsiia s mezhdunarodnym uchastiem, posviashchennaia pamiati E. S. Pushkova. 8-9 noiabria 2007g. Tezisy dokladov [E. S. Pushkova ConferencePresentations. III Scholarly-Practical Gerontological Conference with International Participation, Dedicated to E. S. Pushkova. Nov 8-9, 2007. Theses]. St. Petersburg: 17-19.

Grigoryeva I. (2011) Razvitie sotsial'noi raboty v rossiiskom obshchestve potrebleniia [Development of Social Work in Russian Consumer Society]. Zhurnal sotsiologiii i sotsial 'noi antropologii [Journal of Sociology and Social Anthropology], 5 (14):287-297.

Harris J. G. (2007) Images of the Elderly and Aging in the Contemporary Russian Press. ICCEES Congress, Berlin, August 2007

Harris J.G. (2011) Serving the Elderly: Informal Care Networks and Formal Social Services in St. Petersburg. In M. Jappinen, M. Kulmala, A. Saarinen (eds.) Gazing at Welfare, Gender and Agency in Post-Socialist Countries. Cambridge: Cambridge Scholars Publishing: 78-103.

Hills W.E. (2016) Professor of Gerontology, University of Coastal Carolina, USA. Personal Correspondence 30.09.2016.

Iarskaia-Smirnova E. (2002) Sotsial'naia politika i sotsial'naia rabota v izmeniaiushcheisia Rossii [Social policy and social work in a changing Russia]. Moscow: INION RAN.

Iarskaia-Smirnova E. (2004) Sotsial'naia politika i sotsial'naia rabota: Gendernye aspekty [Social Ppolicy and Social Work: Gender issues]. Moscow: Rosspen.

IAGG (2007) VI European Congress of IAGG. Available at: http://iagg.info/xe/iagg_archives/24 (accessed 6 February 2018).

Kariukhin E. (ed.) (2002) Gerontologicheskie NKO: ot modelej ukhoda k stanovleniiu sektora. Posobie po sotsial'noi gerontologii dlia personala gerontologicheskih NKO [Gerontological NGOs: From Models of Care to the Establishment of the Sector. A Handbook on Social Gerontology for the Personnel of Gerontological NGOs]. Moscow: Eslan.

Kariukhin E. (2004) Pravovaia podderzhka pozhilykh v usloviakh, sozdannykh obschestvennymi organizatsiami [Legal Support of the Elderly under Conditions Stipulated by the Social Organizations]. Uchenye zapiski RGSU [The RSSU Proceedings], 6 (44):28-30.

Kariukhin E. (2005) Rol' obshchestvennykh organizatsii v zashchite prav pozhilykh liudei [The Role of Social Organizations in Defending the Rights of the Elderly]. Predstavitel'naja vlast'XXI vek: zakonodatel'stvo, kommentarii, problemy [Representative Power -XXI century: Legislation, Commentary, Problems], 6 (66):35-37. 
Kariukhin E. (ed.) (2006a) Compact Discs: Pozhilye liudi: Zashchita prav i sotsial'naia podderzhka. Izbrannye materialy po gerontologii [CDs: Defending the Rights of the Elderly and Social Support. Selected Readings in Gerontology]. Moscow: Dobroe Delo and European Commission.

Kariukhin E. (2006b) O sozdanii i vnedrenii Uchebnoi programy 'Rossiiskie i mezhdunarodnye zaschity prav pozhilykh liudei' [On the Creation and Implementation of the Educational Program 'Russian and International Defence of the Rights of the Elderly]. Pushkovskie Chteniia. II Nauchno-prakticheskaia gerontologicheskaia konf erentsiia s mezhdunarodnym uchastiem, posviashchennaia pamiati E.S. Pushkova. 30 noiabria-1 dekabria 2006 g. Tezisy dokladov. [Pushkova Conference Presentations. II Scholarly-Practical Gerontological Conference with International Participation, Dedicated to the Memory of E. S. Pushkova. Nov 30-Dec 1, 2006. Theses.]. St. Petersburg:48-50.

Kariukhin E. (ed.) (2006c) Utverzhdaia Prava Pozhilykh: Gerontologicheskie NKO Severo-Zapada Rossii: Sbornik Materialov [Affirming the Rights of the Elderly: Gerontological NGOs of Northwest Russia: A Collection of Articles]. Moscow: Dobroe Delo.

Kariukhin E. (ed) (2007) Dobroe Delo: 7 let razvitiia i dostizhenii v oblasti grontologicheskogo ukhoda [Dobroe Delo: 7 Years of Development and Achievements in Gerontological Care]. Moscow: Dobroe Delo.

Panich L. (ed.) (2004-2009) Zdravstvui, Pensioner! St. Petersburg: St. Petersburg Centers for Social Services.

Petrushevskaia L. (2001) Vremia noch' [The Time Is Night]. Moscow: Vagrius.

President of Russia (2010) Excerpts from Speech at State Council Presidium Meeting, October 25, 2010. Available at: En.kremlin.ru/events/president/transcripts/9594 (accessed 10 Dec 2010).

President of Russia (2014) State Council Presidium meeting on Developing Social Protection System for Senior Citizens. Available at: http://news.kremlin.ru/transcripts/46397 (accessed 9.10.2016).

Romm T., Romm M., Skalaban I. (1999) Istoricheskie ocherki rossiiskoi sotsial'noi raboty [Historical Essays on Russian Social Work]. Novosibirsk: NGPU.

Tarasenko A. (2015) Russian Welfare Reform and Social NGOs: Strategies for Claim-Making and Service Provision in St Petersburg. East European Politics, 31 (3):294-313.

The Government Decree RF (2002) O federal'noy tselevoy programme 'Starshee pokolenie' na 2002-2004 gody [On the Federal Specially Designated Plan 'Older Generation' for 2002-2004] N 70 from 29.01.2002. Available at: http://base.garant.ru/184125/ (accessed 9 Oct 2016).

The Russian Government (2015) Strategiia deistvii v interesakh starshego pokoleniia v RF do 2025 goda [The Strategy for Action in the Interests of the Older Population in the RF until 2025] N 164p from 05.02.2016. Available at: http://government.ru/docs/21692/ (accessed 9 October 2016).

Thomson K. (2011) Making Sense of Welfare at the Micro Level: Reflections on Disability Research in Russia. M. Jappinen, M. Kulmala, A. Saarinen (eds.) Gazing at Welfare, Gender and Agency in Post-Socialist Countries. Cambridge: Cambridge Scholars Publishing: 38-59.

Tragakes E. (ed.) (2003) Healthcare Systems in Transition: Russian Federation. Copenhagen: European Observatory on Health Systems and Policies.

United Nations (2002) Madrid Plan of Action and its Implementation. Available at: https://www. un.org/development/desa/ageing/madrid-plan-of-action-and-its-implementation.html (accessed 29 July 2017).

Wong S., Altman E., Rojas-Mora J. (2011) Internet Access: Where Law, Economy, Culture and Technology Meet. Computer Networks, 55 (2): 470-479.

Zelenev S. (2008) The Madrid Plan: A Comprehensive Agenda for an Ageing World. NY: United Nations. 